ppi $201502 Z U 4645$

Esta publicación cientifica en formato digital es continuidad de la revista impresa ISSN-Versión Impresa 0798-1406 / ISSN-Versión on line 2542-3185Depósito legal pp

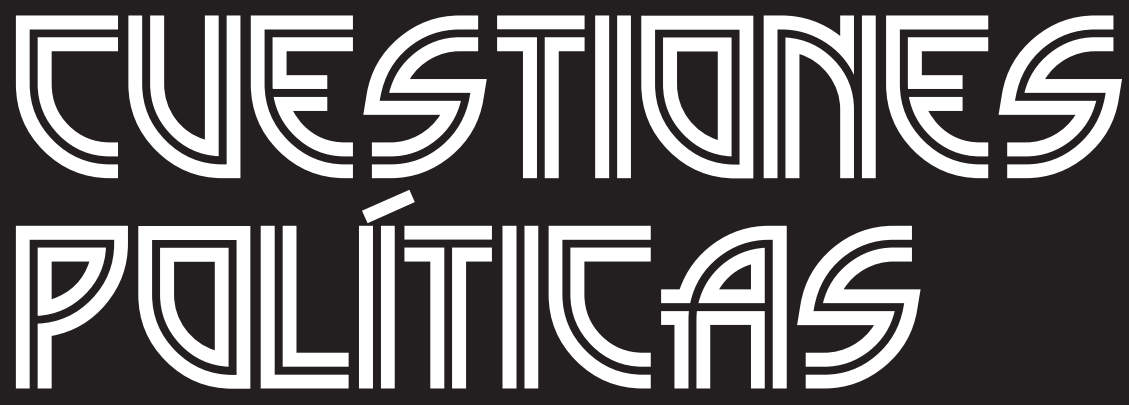

Instituto de Estudios Políticos y Derecho Público "Dr. Humberto J. La Roche' de la Facultad de Ciencias Jurídicas y Políticas de la Universidad del Zulia Maracaibo, Venezuela
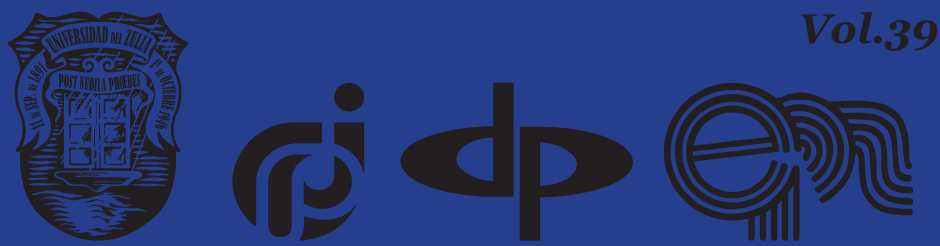


\title{
Formation and development of the foreign policy of the Republic of Turkey with the Turkic-speaking states of Central Asia
}

\author{
DOI: https://doi.org/10.46398/cuestpol.3968.13
}

\author{
Farkhad Linarovich Gumarov * \\ Marat Zufarovich Galiullin ** \\ Luiza Kajumovna Karimova *** \\ Elvira Imbelevna Kamaletdinova
}

\section{Abstract}

So far, the country has not had an official document defining the concept of foreign policy of the Republic of Turkey. The relevance of the problem under study lies in the need to define modern approaches to the Foreign Policy of the Republic of Turkey with respect to Central Asian States. The objective of this article is to analyses the evolution of Turkish foreign policy towards Turkish-speaking states since the early 1990swhile determining the role and importance of these states to Turkey. Historical-genetic and chronological methods have been used as tools to support historical study. The historical and genetic method allows to track the dissemination and consistent of changes in the object of this study. In addition, the method of research and presentation of chronological problems contributes to consistent coverage of the peculiarities of significant events of regional and international importance. The study revealed a tendency to transform Turkey's policy towards The Turkish-speaking states of Central Asia, since the collapse of the Soviet Union.

Keywords: International relations; geopolitical regional studies; Turkey's foreign policy; Central Asia; strategic vision.

* Candidate of History Sciences (PhD in history), assistant, Department of regional and Eurasian studies, Institute of International Relations, Kazan Federal University. ORCID ID: https://orcid. org/oooo-0003-0678-0514. Email: Farkhadgumarov@yandex.ru

** Candidate of Historical Sciences, Associate Professor of the Department of regional studies and Eurasian studies, Institute of international relations, Kazan Federal University. ORCID ID: https:// orcid.org/oooo-0002-3798-4328. Email: maratscorpion@yandex.com

*** Candidate of Historical Sciences, Associate Professor, Department of Regional Studies and Eurasian Studies, Institute of International Relations, Kazan Federal University. ORCID ID: https://orcid. org/oooo-0002-0353-8493. Email: LU_KA_S@rambler.ru

**** Assistant, Department of Regional Studies and Eurasian Studies, Institute of International Relations, Kazan Federal University. ORCID ID: https://orcid.org/oooo-0oo3-3619-6335. Email: elvira-imoiv@ mail.ru 
Farkhad Linarovich Gumarov, Marat Zufarovich Galiullin, Luiza Kajumovna Karimova y Elvira Imbelevna Kamaletdinova

\section{Formación y desarrollo de la política exterior de la República de Turquía con los estados de habla turca de Asia Central}

\section{Resumen}

Hasta ahora el país no cuenta con un documento oficial que defina el concepto de política exterior de la República de Turquía. La relevancia del problema en estudio radica en la necesidad de definir enfoques modernos de la política exterior de la República de Turquía con respecto a los Estados de Asia Central. El objetivo de este artículo es analizar la evolución de la política exterior turca hacia los Estados de habla turca desde principios de la década de 1990 y, al mismo tiempo, determinar el papel y la importancia de estos estados para Turquía. Los métodos histórico-genéticos y de problemas-cronológicos se han utilizado como herramientas de apoyo al estudio histórico. El método histórico y genético permite rastrear la divulgación y consistente de cambios en el objeto de este estudio. Además, el método de investigación y presentación de problemas cronológicos contribuye a una cobertura consistente de las peculiaridades de eventos significativos de importancia regional e internacional. El estudio reveló una tendencia a transformar la política de Turquía hacia los Estados de habla turca de Asia Central, desde el colapso de la unión soviética.

Palabras clave: Relaciones internacionales; estudios regionales geopolíticos; política exterior de Turquía; Asia central; visión estratégica.

\section{Introduction}

In 1992, G. Fuller in his work "Turkey Looks East" wrote that the Turkish government was cautious at a time when the status of the "new republics" was not obvious. Turkey tried to avoid any action that could be interpreted as undermining the foundations of the USSR. In Atatürk's legacy, there is a clear warning against all kinds of Panturkist aspirations and big projects that were characteristic of Ottoman Empire politics in its final years. Atatürk called to focus efforts on creating an ethnically homogeneous state within realistic boundaries. In December 1991 after the official collapse of the USSR Turkey's foreign policy changed dramatically (Fuller, 1992). The Turkish academician Sabri Sayari wrote that Turkey had been cut off from the Turkic-speaking regions of the USSR since Stalin's tough policy. During the USSR period, it was impossible to build relations with the Turkicspeaking community (Sayasi, 1994). Indeed, Moscow had the exclusive right to represent the republics of the Union on the international stage. 
After the end of the Cold War, it was difficult for Turkey to start building relations with Azerbaijan and the countries of Central Asia, as these countries remained dependent on Russia, their economy was weakened, a large number of internal problems and negative sentiment in society prevented (Karpat, 2003). During the USSR, it was not fully possible to build relations with related nations, after the collapse of the USSR Turkey had a chance to restore cultural and economic ties (Winrow, 1998).

\section{Methods}

Historical-genetic and problem-chronological methods have been used as supporting tools of historical study. The historical and genetic method allows tracing the consistent disclosure of changes of the object of this study. The problem-chronological method of research and presentation contributes to consistent coverage of the peculiarities of significant events of regional and international importance. The study revealed a tendency to transform Turkey's policy towards the Turkic-speaking States of Central Asia (CA). An important basis of this study is an interdisciplinary approach, which allows combining applied analysis within the framework of the regional scientific tradition, combining it with political analysis. Historicism involves the study of a phenomenon in terms of its development, which is essential for the analysis of inter-State relations at the present stage. This principle allowed us to establish a causal relationship, to find and understand the origins, to highlight important stages of bilateral and multilateral relations.

\section{Results and Discussions}

In the end of the Cold War Turkey's role has largely declined as the threat of the spread of communist ideology has disappeared. Thus, Turkey has lost a key bargaining chip in building relations with the countries of the West (Çelik, 1999).

With the end of the Cold War and the collapse of the Soviet Union, Turkey's importance to the United States and the West began to weaken. By offering itself as a mediator between Western countries and the newly formed States of the Caucasus and Central Asia, Turkey was given a chance to re-increase its international significance.

Since the 1990s (after the collapse of the USSR), the United States has seen Turkey as a mediator in the Central Asian region (Lancaster and Van Dusen, 2005).

After the collapse of the USSR, as a result of the Belovezh Agreement, the non-Slavic republics were abandoned - such a change in the geopolitical situation was perceived by Turkey as an opportunity to increase their 
Farkhad Linarovich Gumarov, Marat Zufarovich Galiullin, Luiza Kajumovna Karimova y Elvira Imbelevna Kamaletdinova

political and economic influence, to act as a developed state integrated into the world system, to act as an example and point of "assembly" for the Turkic-speaking world.

Iran also declared its ambitions in the region. Competition between Iran and Turkey regarding models of state structure in the countries of CA and Transcaucasia is mentioned in several articles of American and European authors. This topic is devoted to the article of S.B. Druzhilovsky "Politics of Turkey and Iran in Central Asia and Transcaucasia" (Druzhilovsky and Khutorskaya, 2003), which demonstrates that all countries of the region have chosen the Turkish model of development.

Turkey and the Turkish political model, based on the principles of secularism, free market, and parliamentary democracy, are examples of the state structure for the Islamic society of the countries of Central Asia (Bülent, 1999). Many researchers noted that the Turkish model was the most attractive for the countries of the region.

At the initial stage of building relations with the newly independent states of Central Asia, Turkey faced a dilemma - to strengthen its influence in the region on its own or to act as an ally of Europe and, especially, the United States; The second option was chosen (Belokrenitsky, 1996).

Turkey demonstrates to the countries of Central Asia: "An example of the successful functioning of a secular political system with elements of Western democracy, which has succeeded in market transformation in the context of the dominance of Islamic adherents" (Malysheva, 2010: 119).

The Turkish model has become a model of state structure for multi-ethnic and multi-religious countries with a predominantly Muslim population. According to the Turkish model, Islam and political democracy can exist within the same state and society (Winrow, 2000).

Turkish model and its broadcast to the countries - former republics of the Soviet Union, traditionally of interest to the United States, since as early as the 1970s, the Green Belt strategy "YešilKušakprojesi" was an integral part of U.S. foreign policy, Proposed to Brzezin President Jimmy Carter, to support Islamic regimes in the Middle East, In Iraq, Turkey, Iran, Third World countries, etc., to counter Islam to Communism.

Ankara was supported by the United States, the United Kingdom and NATO leadership in establishing close ties with the Central African countries between 1991 and 1992, concerned about Iran's expansion in the region (Winrow, 1995).

Turkish author M. Aydin rightly noted that for the United States, the EU and Russia it was preferable not militaristic (Iranian), but democratic Turkish model of development of these countries (Mustafa, 2005). 
The democratization model was primarily supported by the US and EU countries, which also affected its attractiveness.

In 1992, US Secretary of State James Baker openly called on CA leaders to abandon the Iranian model in favor of the Turkish development model (Winrow, 1995).

According to S. Cornell, Iran has been realistic from the beginning about its capabilities in Central Asia and the Caucasus. Aware of the impossibility of transferring the Iranian model to the countries of the region and not wishing to cede influence to Turkey and the United States in countries near its border, Iran supports Russia 's influence (Cornell, 2015).

At a meeting held in January 1992 in the United States with President J. Bush, Turkish Prime Minister S. Demirel announced Turkey 's change of regional status due to the opportunity to influence the political future of the Muslim republics of the CIS, and that Turkey is able to represent their interests in the West (Egorov, 2000). An important agreement was reached that Turkey would provide direct material and financial assistance to the Turkic-speaking CIS countries, but that it would receive compensation for its costs from the United States and other Western countries. In February 1992, the Minister of Foreign Affairs of the Republic of Turkey went on an official visit to four Turkic-speaking republics (CA and Azerbaijan).

Many researchers note that the "Hundred Years Dream" implies Panturkist designs and the creation of the great Turan. Of course, the geopolitical situation of the early 1990 s "opened its head" to representatives of Turkish political circles. But what did the Turks base their ambitions on?

The "Centennial Dream" is related in large part to the perceptions in Turkish society of the collapse of the USSR as the liberation of Turkicspeaking peoples from the "oppression" of Moscow. At the same time, the majority of the Turkic-speaking population never opposed the USSR. Moreover, in 1991, in a referendum on the integrity of the USSR, the overwhelming majority of the population of the "Asian republics" (Lunev, 2007) voted for the preservation of the Union, including in Kazakhstan and Kyrgyzstan.

In the Republic of Turkey, the perception of the state of affairs in the Turkic-speaking republics of the USSR was different, a distinction that was highlighted by both domestic and Turkish researchers.

During the Cold War, Turkey's relations with the regions that later became new states were significantly limited. After the collapse of the USSR, the Republic of Turkey was unable to adjust to new realities in a short time, leading to some uncertainty for strategic purposes.

General understanding and scientific knowledge of the post-Soviet space as a region as a whole for the Turkish intellectual and ruling elite 
Farkhad Linarovich Gumarov, Marat Zufarovich Galiullin, Luiza Kajumovna Karimova y Elvira Imbelevna Kamaletdinova

was limited (Belokrenitsky and Fadeeva, 1997). In many ways, the idea of the USSR as a state in which national regions constantly resist Moscow as a center that operates and surrounds the outskirts was formed in Turkey on the basis of information from representatives of national elites and former national governments that fled the Soviet Union for fear of physical destruction (Saray, 1994).

This information about the state of affairs in the Soviet Union, which had a negative ideological color, was disseminated in a somewhat exaggerated form in Turkish society. It was with such representations that the Turkish authorities came to the post-Soviet space, so they were not ready to meet with the real state of affairs (Yalçı, 1994).

Turkey's ambitious plans of the 1990s, related primarily to Turkicspeaking regions, were disconnected from reality, and often caused rejection in newly formed Turkic-speaking states. Many statements by the leaders of these countries can be cited, confirming the rejection of Turkey 's assertive and unduly ambitious foreign policy of those years.

The most famous and indicative in this regard is the opinion of the President of Kazakhstan N. Nazarbayev, which he expressed in his book "On the Threshold of the XXI Century":

It seemed to many that Turkey will be able to solve all our problems. But what did it mean in fact? This meant renouncing the independence just gained, breaking traditional relations with neighbors, instead of one "older brother" putting another on his neck (Nazarbayev, 1996: 42).

More rigid was the assessment of the President of Uzbekistan I. Karimov - he called in vain Turkey's hopes "to interfere in our internal life and manage us," while noting: "Turkey wants us to become Turks. We are Uzbek, not Turks" (Basharan, 2018: 58).

All references to Turkey's politics related to Panturkism and Panturanism, Refer to the early 1990s. Such - based on misconceptions about the republics of the USSR, On the departure of the Democratic Party from the principles of kemalism in foreign policy - the activity showed its failure as early as 1992, When, at the first Turkic-speaking summit, the leaders of the participating countries refused to sign documents prepared in advance by the Turkish host country on the establishment of a common bank and any supranational institutions.

Aware of the naivety of the ambitions of Panturkism and the limitations of its political and economic opportunities to realize what it intended, Ankara embarked on a transformation of foreign policy, not wanting to remain a "periphery," as it was during the Cold War. Turkey has applied for the role of regional power (Urmanov, 2014). Despite a number of 
failures related to Turkey's overly ambitious policy of the 1990s, and close ties between the Central African regions and Russia, Turkey managed to establish relations with the countries of the region using ethnic, historical, cultural and religious ties (Kemal, 1995).

\section{Conclusion}

The violent processes that took place in the Eurasian region in the early 1990 s led to two "intellectual" consequences in Turkey. On the one hand, "the sudden rediscovery of almost forgotten peoples of Turkic origin led to inflated hopes and unrealistic expectations from some Turkish officials." However, on the other hand, it was the collapse of the Soviet Union that allowed Turkey to overcome its own "Panturanism complex" and establish relations with Turkic-speaking states, to present the true face of Turkey outside it, the opposite of the aggressive appearance in which it is sometimes depicted.

Political processes in Central Asia since the collapse of the USSR and the formation of new states have aroused great scientific interest among researchers. For domestic historiography, this issue has its own specificity, as the countries that were part of the USSR are traditionally considered zone of Russian geopolitical interests. Therefore, the policy of other States in the region has always attracted special attention from the public and scientific circles, and the active policy of the Republic of Turkey is naturally perceived as competition. This has a bearing on their study of Turkey's policies in the region and is often directly or indirectly focused on possible threats. Thus, Turkey's policy in Central Asia was considered by E.I. Urazova, N.G. Kireev, B.M. Pozhveria, S.B. Druzhilovsky, N.Y. Ulchenko, V.A. Nadin-Raevsky, etc.

Western historiography (G.E. Fuller, S. Cornell, 1999; B.Luis, G. Winrow, S. Komel, F.C. Larrabi, etc.) often addresses Turkey's policy issues in the Central Asian region, the general state and depth of study of the Turkish Republic's policy towards Turkic-speaking countries included in the EAEU should be considered insufficient. In the 1990s, Western researchers were most interested in the general understanding of the processes that took place in these countries after the collapse of the USSR. Modern research emphasizes the strengthening of the Islamic component in Turkey's politics. American historiography focuses on the modern concept of Turkey's foreign policy. Researchers are primarily concerned about the rise of Islamization and the associated risks of Turkey abandoning Western values and moving away from the United States. 
Farkhad Linarovich Gumarov, Marat Zufarovich Galiullin, Luiza Kajumovna Karimova y Elvira Imbelevna Kamaletdinova

Formation and development of the foreign policy of the Republic of Turkey with the Turkicspeaking states of Central Asia

\section{Acknowledgements}

The work is performed according to the Russian Government Program of Competitive Growth of Kazan Federal University.

\section{Bibliographic References}

BASHARAN, Venera. 2018. The Role of the Regions in Russian-Turkish Economical Relationship at the Present Stage (Based on the Example of the Republic of Tatarstan). National Academy of Managerial Staff of Culture and Arts Herald. Выпуск: No. 3, pp. 374-376.

BELOKRENITSKY, Vyacheslav Ya. 1996. "Central Asia in the Eurasian Perspective” In: East, No. 6, pp. 94-95.

BELOKRENITSKY, Vyacheslav Ya; FADEEVA, Iilliam L. 1997. Features of modernization in the Muslim East. The experience of Turkey, Iran, Afghanistan, Pakistan. M. IV RAS. Moscow, Russia.

BÜLENT, Aras. 1999. Central Asian Relations: A View from Turkey. Avrasya Dosyasi. p. 3.

ÇELIK, Yasemin. 1999. Contemporary Turkish Foreign Policy. The U.S. Prager. New York, USA.

CORNELL, Svante E. 1999. "Geopolitics and strategic alignments in the Caucasus and Central Asia" In: Perceptions Journal of International Affairs. Available online. In: https://dergipark.org.tr/en/download/ article-file/817114. Consultation date: 04/09/2019.

DRUZHILOVSKY, Sergey B; KHUTORSKAYA, Victoria V. 2003. Politics of Turkey and Iran in Central Asia and the Caucasus. Iran and the CIS. ed. N.M. Mamedova. - M . IV RAS, Institute for the Study of Israel and the Middle East. p.223

EGOROV, Villy K. 2000. Russia and Turkey: the line of contradictions. East and modernity. M. - p. 323.

FULLER, Graham E. 1992.Turkey Faces East New Orientations Toward the Middle East and the Old Soviet. Published by RAND. Santa Monica, USA.

KARPAT, Kemal H. 2003. Türkiyeve Orta Asya (Translated in Turkish by Hakan Gür). Imge. Ankara, Turkey. (In turkish).

KEMAL, Karpat. 1995. The Sociopolitical environment conditioning the Foreign Policy of the Central Asian states. Sharpe. New York, USA. 
LUNEV, Sergei Ivanovich. 2007. "Political processes in Central Asia. Formation of statehood in the republics of the region" In: Political systems and political cultures of the East / ed. prof. HELL. Voskresensky. M. Moscow, Russia.

MALYSHEVA, Dina Borisovna. 2010. Central Asian hub of world politics. M. IMEMO RAS. p. 66.

MUSTAFA, Aksoy. 2005. Turkianinorta Asya - Kafkaslarpolitikasi. Nobel. Ankara, Turkey. (In turkish).

NAZARBAYEV, Nursultan. 1996. On the Threshold of the 21st Century. Almaty. Moscow, Russia.

SARAY, Mehmet. 1994. "Çarlikve Soveyet Dönemin de Ruslar in Türkler hakkindaki Göröşlerive Siyasetleri” In: Avrasia Etudleri. No. 3, pp. 1533. (In Turkish).

SAYASI, S. 1994. Turkey, the Caucasus and Central Asia in The New Geopolitics of Central Asia and Its Borderlands. Ali Banuazizi\& Myron Weiner (Ed). I.B. Tauris. London, England.

URMANOV, Dayan R. 2014. The Central Asian factor in Turkish foreign policy. Materials of the international conference "Turkey: new realities in domestic politics". MGIMO - University. Moscow, Russia. (In Russo).

WINROW, Gareth M. 1995. Turkey in Post-Soviet Central Asia. Royal Institute of International Affairs. London, England.

WINROW, Gareth M. 1998. Turkish Policy in Central Asia. Touraj Atabaki \& John O`Kane (Ed), Post-Soviet Central Asia. IIAS. New York, USA.

WINROW, Gareth M. 2000. Turkish Policy towards Central Asia and the Transcaucasia, in Turkey's New World Changing Dynamics in Turkish Foreign Policy, Alan Makovsky and Sabri Sayari (Ed). The Washington Institute for Near East Policy. Washington DC, USA.

YALÇIN, Aydın. 1994. "Tarih Perspektifinden Orta Asya `nin Gelecegi” In: Avrasya Etudleri Ankara. No 1, pp. 19-40. (In Turkish).

LANCASTER, Carol; VAN DUSEN, Ann. 2005. Kazakhstan had nuclear infrastructure. The U.S. gave Kazakhstan a high amount of aid at this period. Organizing U/S/ foreign Aid: Confronting the Challenges of the Twenty-First Century. The Brooking institutions. Washington, USA. 
ISSN 0798-1406 Depósito legal pp 198502ZU132

\section{Cuestiones Políticas}

\section{Planilla de suscripción}

Nombre

Institución

Dirección

Ciudad País

Cheque de gerencia a nombre de: Universidad del Zulia (LUZ),

Facultad de Ciencias Jurídicas y Políticas, Ingresos Propios

Banco Occidental de Descuento, Cuenta corriente № 212700890-9

Tarifa de suscripción por un año (dos números):

Venezuela: Bs. 80 + Envío

Ejemplar solo: Bs. $40+$ Envío

América Latina \$ $40+$ Envío

Resto del mundo $\$ 50+$ Envío

Esta planilla debe ser enviada a la siguiente dirección:

Revista "Cuestiones Políticas"

Facultad de Ciencias Jurídicas y Políticas

Instituto de Estudios Políticos y Derecho Público

Apartado Postal 526, Maracaibo Venezuela

Puede adelantar información por: cuestionespoliticas@gmail.com

loichirinosportillo@gmail.com 